\title{
Inheritance and Mapping of Stem Rust Resistance of Wheat Line PI 410966
}

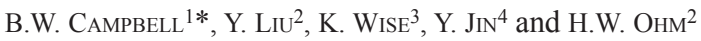 \\ ${ }^{1} 1991$ Upper Buford Circle, 411 Borlaug Hall, St. Paul, MN, 55108, USA \\ ${ }^{2}$ Dep. of Agronomy 915 W. State St., West Lafayette, IN 47907, USA \\ ${ }^{3}$ Dep. of Botany and Plant Pathology, 915 W. State St., West Lafayette, IN 47907, USA \\ ${ }^{4}$ USDA-ARS Cereal Disease Laboratory, St. Paul, MN, USA
}

(Received 3 December 2015; Accepted 15 February 2016;

Communicated by J. Kolmer)

\begin{abstract}
Stem rust caused by Puccinia graminis f. sp tritici of wheat (Triticum aestivum L.) is one of the most destructive cereal diseases globally. Concern about the disease has increased since 1999 with the discovery in Uganda of a new virulent race of $P g t$, designated as race TTKSK (also known as Ug99). The objectives of this experiment were to characterize the resistance and to determine the chromosomal location of the stem rust resistance in the spring wheat line PI 410966. A mapping population was developed from a cross between PI 410966 and a susceptible wheat line OK3040. An inoculation test with isolate 04KEN156/04 of race TTKSK was conducted at the USDA-ARS Cereal Disease Laboratory in the $\mathrm{F}_{6: 7}$ generation, and the $\mathrm{F}_{6: 7}$ phenotypic data were used to genetically map the resistance gene to the centromeric region on chromosome $2 \mathrm{BS}$. The single locus explained the observed $\mathrm{F}_{6: 7}$ resistant and susceptible scores. The location of the gene and molecular marker banding profiles of the diagnostic markers suggest that the stem rust resistance gene in PI 410966 could be a new gene, an allele of $\operatorname{Sr} 36$, or $\operatorname{Sr} 36$.
\end{abstract}

Keywords: Puccinia graminis, wheat stem rust, Ug99, Sr36, resistance gene

Abbreviations: Pgt - Puccinia graminis f. sp. tritici; BSA - bulked segregant analysis; $\mathrm{PCR}$ - polymerase chain reaction; SSR - simple sequence repeat

\section{Introduction}

Stem rust, caused by Puccinia graminis Pers.:Pers. f. sp. tritici Eriks. \& E. Henn. (abbreviated as $P g t$ ) is one of the most destructive cereal diseases globally. This fungus can infect all above-ground portions of the plant and can occur in most areas where wheat (Triticum aestivum L.) is grown. Numerous stem rust epidemics have caused significant yield and economic losses in the United States, Europe, Asia, and Australia in the $20^{\text {th }}$ century (Zadoks 1963; Rees 1972; Roelfs 1977; Leonard 2001; Leonard and Szabo 2005). Specifically, from 1920 to 1960 losses of up to 50\% were reported in the United States due to stem rust (Leonard 2001). The use of resistance genes is the most effective and

\footnotetext{
*Corresponding author; E-mail: campb964@umn.edu
} 
economical method to protect wheat from stem rust, and thus resistance genes have become the primary management tool for this disease (McIntosh 1988). The efficacy of breeding efforts against stem rust is shown by the decrease in both the number and in the severity of stem rust epidemics since the 1970's (Leonard and Szabo 2005; Jin and Singh 2006).

The discovery of a new stem rust race, TTKSK, in 1999 has caused considerable concern, because this race is virulent against the widely deployed $\mathrm{Sr} 31$ and $\mathrm{Sr} 38$ resistance genes (Pretorius et al. 2000). This race was classified as TTKSK based on the North American nomenclature system (Roelfs and Martens 1988; Wanyera et al. 2006; Jin et al. 2008). This new race poses a serious threat to East Africa and to the Middle East since a majority of the wheat cultivars grown in these regions are susceptible to race TTKSK (Reynolds and Borlaug 2006). Thus, significant crop and economic losses may occur in these areas unless genes that provide resistance to race TTKSK are deployed (Singh et al. 2011). It is necessary to identify and genetically map new sources of resistance in order to have multiple resistance genes that can be utilized to protect wheat from race TTKSK and its variants. Combining resistance genes together, a process called pyramiding, increases the durability of resistance genes (Pederson and Leath 1988; Leonard and Szabo 2005). However, combining multiple resistance genes that provide effective resistance to the same pathogen can be difficult without the use of molecular markers (Anderson 2003; Kuchel et al. 2007). The objectives of this study were to characterize the resistance and to map the source of resistance in PI 410966 that is effective against Pgt race TTKSK.

\section{Materials and Methods}

\section{Plant materials}

A spring wheat line, PI 410966, from the Bethlehem Research Station, Bethlehem, South Africa, was identified as resistant to race TTKSK in 2005 and 2006 by the United States Department of Agriculture-Agriculture Research Service (USDA-ARS) in international stem rust nurseries at Kenyan Agriculture Research Institute (Jin, unpublished data). In order to understand the genetics of this resistance and to map the resistance gene, PI 410966 was crossed to line OK3040 to generate a population of 147 individuals, which was advanced by single seed descent. OK3040 (kindly provided by Dr. Art Klatt, Oklahoma State University) is a facultative winter wheat line requiring only minor vernalization and is susceptible to race TTKSK (Klatt, personal communication).

\section{Stem rust evaluation}

$\mathrm{F}_{6: 7}$ progeny and the parental lines were tested using isolate 04KEN156/04 of Pgt race TTKSK at the USDA-ARS Cereal Disease Laboratory (St. Paul, MN). The genetic material for this test was composed of eight to ten seeds per line from bagged heads in the previous generation which insured only self-pollination. The test was conducted following protocols described by Jin et al. (2007). 


\section{Marker analysis}

Lines were selected for bulked segregant analysis (BSA) using the $\mathrm{F}_{6: 7}$ seedling stem rust phenotype data (Michelmore et al. 1991). Ten resistant lines were chosen for the resistant bulk, and ten susceptible lines were chosen for the susceptible bulk. DNA concentrations for the lines composing the bulks were standardized, and then equal volumes of each line's DNA were mixed together in their specific bulk $1.5 \mathrm{~mL}$ tube.

DNA was extracted from leaf samples from individual plants in the $\mathrm{F}_{6: 7}$ generation and used to create the resistant and susceptible bulks. The DNA extraction protocol was modified from the protocol by Pallotta et al. (2003). The modifications included: grinding fresh leaf tissue using grinding rods and performing the DNA extraction procedure in 1.5 $\mathrm{ml}$ tubes. The pellets were rehydrated with $100 \mu \mathrm{L}$ of $\mathrm{ddH}_{2} \mathrm{O}$, and the DNA concentration was measured by a NanoDrop1000 Spectrophotometer (Thermo Fisher Scientific, Wilmington, DE). DNA concentrations were adjusted to a final standard concentration of 80 $\mathrm{ng} / \mu \mathrm{L}$.

To screen the genome, three or more Simple Sequence Repeat (SSR) markers were selected for testing on each arm of the 21 wheat chromosomes according to the consensus map by Somers et al. (2004). The markers screened were from the BARC, CFA, CFD, GDM, GWM, and WMC sets (Röder et al. 1998; Pestsova et al. 2000; Gupta et al. 2002; Somers et al. 2004; Song et al. 2005). Additional markers were screened as necessary to increase marker density.

SSR markers, amplified by polymerase chain reaction (PCR), were used to identify genetic polymorphisms. The PCR reaction consisted of the following reagents: $11.3 \mu \mathrm{L}$ $\mathrm{ddH}_{2} \mathrm{O}, 2.5 \mu \mathrm{L}$ 10X Buffer, $2.5 \mu \mathrm{L}$ of $2.5 \mathrm{mM}$ dNTPs, $1.5 \mu \mathrm{L}$ of $25 \mathrm{mM} \mathrm{MgCl}_{2}, 2.5 \mu \mathrm{L}$ of $2.5 \mathrm{mM}$ forward primer, $2.5 \mu \mathrm{L}$ of $2.5 \mathrm{mM}$ reverse primer, $0.2 \mu \mathrm{L}$ of $1 \mathrm{U}$ Taq polymerase, and $2.0 \mu \mathrm{L}$ of $80 \mathrm{ng} / \mu \mathrm{L}$ DNA for a total reaction volume of $25 \mu \mathrm{L}$. PCR products tested through the Purdue University Genotyping Center's ABI 3700 DNA Analyzer (Applied Biosystems, Foster City, CA), consisted of PCR reactions using the following reagents: $6.02 \mu \mathrm{L} \mathrm{ddH}{ }_{2} \mathrm{O}, 1.0 \mu \mathrm{L} 10 \mathrm{X}$ Buffer, $1.0 \mu \mathrm{L}$ of $2.5 \mathrm{mM}$ dNTPs, $0.6 \mu \mathrm{L}$ of $25 \mathrm{mM} \mathrm{MgCl}_{2}$, $0.15 \mu \mathrm{L}$ of $10.0 \mathrm{mM}$ fluorescently labeled forward primer, $0.15 \mu \mathrm{L}$ of $10.0 \mathrm{mM}$ reverse primer, $0.08 \mu \mathrm{L}$ of $1 \mathrm{U}$ Taq polymerase, and $1.0 \mu \mathrm{L}$ of $80 \mathrm{ng} / \mu \mathrm{L}$ DNA for a total reaction volume of $10 \mu \mathrm{L}$. The forward primer was fluorescently labeled with one of four different fluorescent dyes: FAM, VIC, NED, or PET. All PCR reactions were run in a MyCycler Thermocycler (Bio-Rad, Hercules, California) using a Touchdown protocol modified from the protocol described by Korbie and Mattick (2008). The PCR reaction utilized was a Touchdown protocol with one cycle at $95{ }^{\circ} \mathrm{C}$ for four minutes, followed by six cycles of $94{ }^{\circ} \mathrm{C}$ for $45 \mathrm{~s}, 68^{\circ} \mathrm{C}$ for five minutes, $72{ }^{\circ} \mathrm{C}$ for one minute with a decrease in the annealing temperature of $2{ }^{\circ} \mathrm{C}$ on each repeat. These cycles were followed by eight cycles of $94{ }^{\circ} \mathrm{C}$ for $45 \mathrm{~s}, 58^{\circ} \mathrm{C}$ for five minutes, $72{ }^{\circ} \mathrm{C}$ for one minute with a decrease in the anneal temperature of $1{ }^{\circ} \mathrm{C}$ on each repeat. These cycles were followed by 25 cycles of $94{ }^{\circ} \mathrm{C}$ for $45 \mathrm{~s}, 50^{\circ} \mathrm{C}$ for two minutes, $72^{\circ} \mathrm{C}$ for one minute, and finishing with a final seven minute extension at $72{ }^{\circ} \mathrm{C}$. The final cycle was set to incubate at $4{ }^{\circ} \mathrm{C}$ indefinitely. The PCR prod-

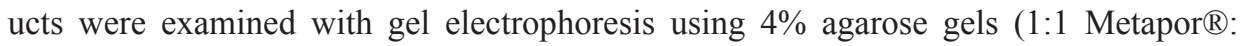


Seakem $\left.{ }^{\circledR}\right)$ stained with ethidium bromide. Gels were imaged in a Kodak Gel Logic 200 Imagine System (Rochester, New York).

A slightly different procedure was used for preparing the PCR products to be run on Purdue University's Genotyping Center ABI 3700 DNA Analyzer. The PCR reaction was conducted as described above, and then four PCR reactions that used different fluorescently labeled primers were multiplexed together into a new 96-well plate following the protocol by Varshney et al. (2009). Genotyping results were analyzed with the software GeneMarker (version 1.91, Soft Genetics LLC® State College, PA).

\section{Linkage analysis}

The marker data were analyzed using JoinMap ver. 4.1 (Van Ooijen 2012) with a Logarithm of Odds (LOD) threshold of 3.0. The Kosambi function was used to calculate the genetic distance in centimorgans (cM) (Kosambi 1944). Dominant, recessive, and codominant markers were all used to map the resistance gene.

\section{Results}

\section{Phenotype results}

For the $\mathrm{F}_{6: 7} P g t$ test with race TTKSK, lines with infection type (IT) ranging from $0-0$;, ; $; 1, ; 1^{+}$, and $; 13^{-}$were classified as resistant, and lines with IT 3 to 4 were classified as susceptible (Stakman et al. 1962; Roelfs and Martens 1988). IT of PI 410966 was ; 1 to ;13-, and OK3040 had an IT of 4. From the population: 96 lines were resistant, 46 lines were susceptible, and 5 lines were segregating. This population did not follow the expected approximate 1:1 segregation ratio of resistant to susceptible as would be expected for a RIL population (Table 1).

\section{Mapping results}

A total of 264 SSR markers were tested on the parents, and from these, 123 polymorphic markers were selected for testing on the resistant and the susceptible bulks. From the 123 markers screened, 39 markers were chosen to run on the individual lines composing the bulks. Fourteen of these 39 markers were selected to genotype the entire population to map the resistance gene. A total of fourteen SSR markers mapping to a total of sixteen loci were identified in the stem rust resistance linkage group giving a map length of

Table 1. Chi-square tests of seedling stem rust response segregation in $\mathrm{F}_{6: 7}$ families when inoculated by $P g t$ race TTKSK

\begin{tabular}{|c|c|c|c|c|c|}
\hline Generation & Total & Observed ratio* & Expected ratio & $\mathrm{X}^{2}$ & P-value \\
\hline $\mathrm{F}_{6: 7}$ & 147 & $96: 5: 46$ & $71: 5: 71$ & 17.6 & $<0.001$ \\
\hline
\end{tabular}

*Observed ratios are for non-segregating resistant: segregating: non-segregating susceptible families. 


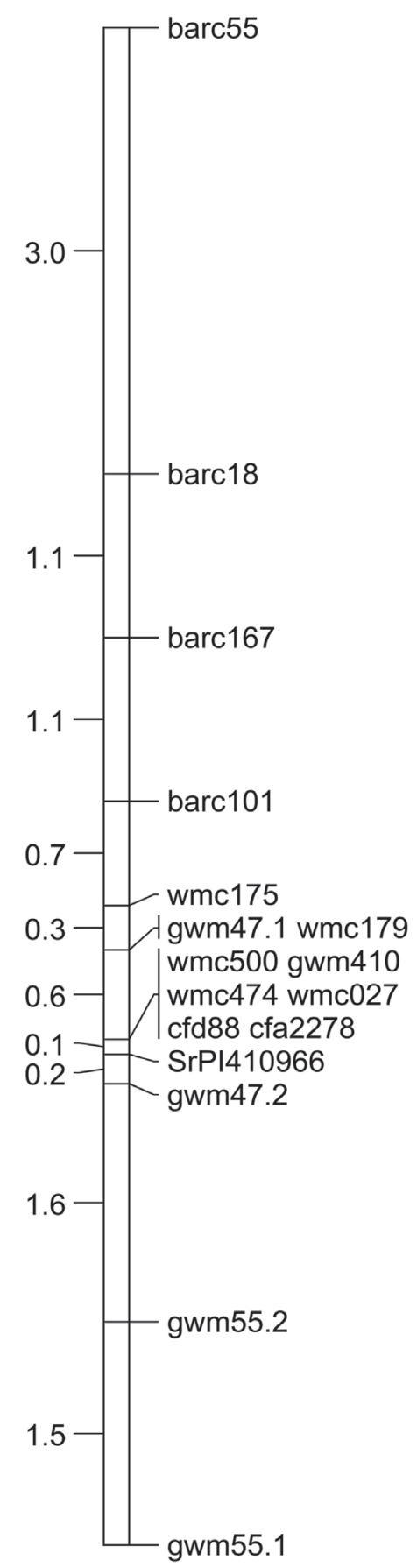

Figure 1. Chromosome 2BS genetic linkage map depicting the location of the stem rust resistance gene SrPI410966 in wheat line PI 410966 effective against TTKSK (Ug99). Map distances between markers are given in $\mathrm{cM}$

$10.2 \mathrm{cM}$ (Fig. 1). Two of the SSR markers produced a second amplicon which could be mapped to a second location, resulting in a total sixteen loci from fourteen SSR markers. Of the fourteen total SSR markers used, eight of the markers mapped to nine loci within $1 \mathrm{cM}$ of either side of the resistance locus.

Of the seven markers tightly linked with resistance, four markers: Xcfa2278, Xgwm410, Xwmc27, and $X w m c 474$, were positioned on chromosome 2BS and two markers: Xwmc500 and Xgwm47, were positioned on chromosome $2 \mathrm{BL}$ according to the consensus map by Somers et al. (2004). Most of the linked markers were previously mapped to $2 \mathrm{BS}$, suggesting that the location of the stem rust resistance gene in PI 410966 is positioned on the short arm of chromosome $2 \mathrm{~B}$. Of the markers tested, four co-dominant markers were found to segregate closely with resistance: $X c f a 2278$, $X g w m 410, X w m c 27$, and Xwmc474.

The molecular marker banding profiles PI 410966 and a wheat line with $S r 36$ were compared to see if SrPI410966 might be Sr36 (Table 2). The markers identified in this study were run on INW0411, a line containing Sr36 (HW Ohm, unpublished) to compare the diagnostic molecular marker banding profile of PI 410966 to a Sr36 containing line. In addition, four molecular markers linked to Sr36 were tested on PI 410966 to identify if PI 410966 produced the molecular marker banding profile diagnostic for Sr36. The markers Xcfa2278, Xcfd88, Xgwm410, Xwmc27, Xwmc474, and $X w m c 500$ identified in this study as segregating with SrPI410966 were tested on INW0411, and these markers did not show significantly different marker banding profiles between PI 410966 and INW0411. However, for Xgwm47.2, PI 410966 amplified critical bands with the sizes $182 \mathrm{bp}$ and $184 \mathrm{bp}$, while INW0411 did not amplify these bands. PI 410966 was genotyped as having all of the Sr36 diagnostic amplicons for the molecular markers Xgwm319,Xgwm429, Xwmc477, and 
Table 2. Amplicon sizes for diagnostic molecular markers linked to Sr36, SrPI410966, and Sr40

\begin{tabular}{|c|c|c|c|c|}
\hline $\begin{array}{r}\text { Line: } \\
\text { Resistance Gene: }\end{array}$ & $\begin{array}{l}\text { PI } 410966 \\
\text { SrPI410966 }\end{array}$ & $\begin{array}{l}\text { INW0411 } \\
\text { Sr36 }\end{array}$ & $\begin{array}{c}\text { RL6088 } \\
\text { Sr40 }\end{array}$ & \\
\hline Molecular Marker & \multicolumn{3}{|c|}{ Amplicon size (bp) } & Marker diagnostic for \\
\hline Xgwm319 & 170 & 170 & & Sr36 \\
\hline Xgwm 429 & 220 & 220 & & $\operatorname{Sr} 36$ \\
\hline Xwmc477 & $165,190,195 \& 235$ & 190 & & Sr36 \\
\hline Xstm773-2 & 155 & 155 & & $\operatorname{Sr} 36$ \\
\hline Xcfa2278 & 131,132 & 131,132 & & SrPI410966 \\
\hline Xcfd88 & (band absent) & (band absent) & & SrPI410966 \\
\hline Xgwm 410 & $309,310,311$ & $309,310,311$ & & SrPI410966 \\
\hline Xwmc27 & 382 to 388 & 382 to 388 & & SrPI410966 \\
\hline Xwmc474 & $124,127,129$ & $124,127,129$ & & SrPI410966 \\
\hline Xwmc500 & 149 & 149 & & SrPI410966 \\
\hline Xgwm 47.2 & $182 \& 184$ & na & & SrPI410966 \\
\hline Xwmc344 & $215,250 \& 300$ & & 264 & $\mathrm{Sr} 40$ \\
\hline Xgwm 374 & 180 & & 234 & $\mathrm{Sr} 40$ \\
\hline Xwmc474 & $124,127 \& 129$ & & 150 & $\operatorname{Sr} 40$ \\
\hline Xbarc18 & (band absent) & & 260 & $\mathrm{Sr} 40$ \\
\hline Xwmc477 & $165,190,195 \& 235$ & & 180 & $\operatorname{Sr} 40$ \\
\hline
\end{tabular}

Notes: Diagnostic amplicon sizes for $\operatorname{Sr} 36$ were determined by Tsilo et al. (2008), and diagnostic amplicon sizes for $\mathrm{Sr} 40$ were determined by $\mathrm{Wu}(2008)$. na - non-available.

Xstm773-2 (Tsilo et al. 2008). The similarity of the molecular marker banding profiles suggest that SrPI410966 is either closely positioned to Sr36, is an allele of Sr36, or is $\operatorname{Sr} 36$ (Table 2).

The molecular marker banding profile of PI 410966 and $S r 40$ were compared to see if SrPI410966 might be $S r 40$ (Table 2). DNA of a wheat line containing $S r 40$ was not available on which to test the diagnostic markers identified for SrPI410966, and so only the Sr40 diagnostic markers were run on PI 410966. PI 410966 was genotyped as having none of the Sr40 diagnostic amplicons for molecular markers Xwmc344, Xgwm374, $X w m c 474, X b a r c 18$, and Xwmc477 (Wu et al. 2009). Thus, Sr40 and SrPI410966 containing lines produced different molecular marker banding profiles for all of the $\mathrm{Sr} 40$ diagnostic markers suggesting that SrPI410966 is not Sr40.

\section{Discussion}

This study characterized the wheat population PI $410966 \times$ OK3040 and genetically mapped the resistance gene in PI 410966 that provides resistance to $P g t$ race TTKSK. F $6: 7$ seedling phenotype data and fourteen SSR markers were used to map the resistance gene 
to the centromeric region on chromosome $2 \mathrm{BS}$. The single gene explained the observed $\mathrm{F}_{6: 7}$ resistant and susceptible scores. Therefore the symbol SrPI410966, is temporarily assigned to the stem rust gene in PI 410966 mapped to 2BS that provides resistance to Pgt race TTKSK.

A segregation ratio close to 1:1 of resistant to susceptible lines is expected in advanced generations of a population for a trait controlled by one gene. Instead of observing a 1:1 ratio, more resistant than susceptible plants were observed (Table 1). Other experiments have observed the same phenomenon of the preferential transmission of a chromosome segment containing a stem rust resistance gene. Nyquist (1962), Bariana et al. (2001) and Tsilo et al. (2008) all observed the preferential transmission of the Sr36 containing chromosome segment on 2BS. In contrast, Wu et al. (2009) observed that the 2BS chromosome segment containing $\mathrm{Sr} 40$ was not preferentially transmitted. The cause of the observed segregation distortion in this study is not known.

SrPI410966 was found to be positioned near the centromere on chromosome 2BS which is also the location of two other stem rust resistance genes: $\mathrm{Sr} 36$ and $\mathrm{Sr} 40$ (Tsilo et al. 2008; Wu et al. 2009). To determine if the SrPI410966 is different from Sr36 and Sr40, crosses need to be made between the lines carrying SrPI410966 and lines carrying Sr36 and $\mathrm{Sr} 40$, and segregation for stem rust resistance needs to be observed. Pedigree data and molecular marker data can also be utilized to help determine if SrPI410966 is unique.

A pedigree of PI 410966 was created from the pedigree information available from the Germplasm Resources Information Network (GRIN) database (http://www.ars-grin. gov/). The parents of PI 410966 are listed as Flameks and H-44-24, a sister selection of the line "Hope". The GRIN database indicates that Flameks was developed at the Winter Rainfall Region Station in Cape Province, South Africa and that H-44-24 was developed by McFadden (1930). There is no pedigree indication that PI 410966 has any common parentage with the sources of $S r 36$ or $S r 40$ both of which were transferred from T. timopheevii (Allard and Shands 1954; Dyck 1992). Thus the pedigree information from the GRIN database suggests that the source of stem rust resistance found in PI 410966 is different from the $\mathrm{Sr} 36$ and $\mathrm{Sr} 40$ sources of stem rust resistance. However, it is possible that lines with $\mathrm{Sr} 36$ or $\mathrm{Sr} 40$ may have accidentally been introduced into the PI 410966 pedigree.

Differences or similarities in the molecular map positions can also be used to suggest that two resistance genes are unique or potentially the same. The use of markers $X w m c 474$ and Xbarc18 by this study and by Wu et al. (2009) allowed the comparison of the molecular maps for Sr40 and SrPI410966. The marker Xwmc474, mapped to $2.5 \mathrm{cM}$ proximal of $S r 40$, is the closest marker mapped to $S r 40$ (Wu et al. 2009). In contrast, this study found marker Xwmc474 mapped to $0.2 \mathrm{cM}$ proximal to SrPI410966. Marker Xbarc18 mapped to $3.9 \mathrm{cM}$ proximal to $S r P I 410966$ and $3.5 \mathrm{cM}$ proximal to $S r 40$ (Wu et al. 2009). The similarity of the SrPI410966 and Sr40 map positions relative to markers Xwmc474 and Xbarc18 suggest that SrPI410966 and Sr40 are positioned near each other on chromosome 2BS. The molecular markers used in this study were not the same as the molecular markers used in studies mapping $\mathrm{Sr} 36$, and thus comparisons between the map positions of $\mathrm{Sr} 36$ and $\mathrm{SrPI} 410966$ could not be made. 
This study identified that PI 410966 contains a single resistance gene, located in the centromeric region on chromosome $2 \mathrm{BS}$, that effectively provides resistance to $\mathrm{Pgt}$ race TTKSK. Two other resistance genes, $\mathrm{Sr} 36$ and $\mathrm{Sr} 40$, have also been previously mapped to the same chromosome $2 \mathrm{BS}$ region. Both pedigree and molecular marker data were utilized to compare $\mathrm{SrPI} 410966$ to $\mathrm{Sr} 36$ and $\mathrm{Sr} 40$. The pedigree data does not support that SrPI410966 is either Sr36 or Sr40; however, lines containing these resistance genes could have accidentally been introduced into the pedigree. The molecular markers identified by Tsilo et al. (2008) and by $\mathrm{Wu}(2008)$ were used to compare SrPI410966 to Sr36 and to Sr40. While SrPI410966 and Sr40 share some similarities in their map positions, the clear differences between the molecular marker banding profiles for all of the $\mathrm{Sr} 40$ diagnostic markers indicate that $\mathrm{SrPI} 410966$ is not $\mathrm{Sr} 40$. In contrast, the molecular marker profiles of INW0411, a line containing Sr36, and PI 410966 were identical for all tested diagnostic molecular markers, with the exception of Xgwm47.2. These results suggest three situations for the gene arrangement; 1) SrPI410966 and Sr36 are closely positioned on 2BS; 2) SrPI410966 and Sr36 are alleles of one another; or 3) SrPI410966 is Sr36. If SrPI410966 and Sr36 are the same gene, this research has identified additional closely linked codominant markers that can be used for marker assisted selection and for fine mapping.

\section{Conflict of Interest}

There is no conflict of interest. Any opinions, findings, conclusions, or recommendations expressed in this publication are those of the authors and do not necessarily reflect the view of the U.S. Department of Agriculture.

\section{Acknowledgements}

The authors would like to thank Sam Gale of the USDA-ARS Cereal Disease Laboratory for help with the stem rust screenings. Research was partially funded by the USDA National Institute of Food and Agriculture, USDA-ARS Competitive Grant \#10-8511720607 and Award No. 58-3620-8-688; and UDSA-ARS Specific Cooperative Agreement 58-3620-8-688. This project was also supported by the USDA-ARS Cereal Disease Laboratory, St. Paul, MN, USA.

\section{References}

Allard, R.W., Shands, R.G. 1954. Inheritance of resistance to stem rust and powdery mildew in cytologically stable spring wheats derived from Triticum timopheevi. Phytopathol. 44:266-274.

Anderson, J.A. 2003. Plant genomics and its impact on wheat breeding. In: Newbury, H.J. (ed.), Plant Molecular Breeding. Blackwell Publ. Boca Raton, FL, USA. pp. 184-215.

Bariana, H.S., Hayden, M.J., Ahmed, N.U., Bell, J.A., Sharp, P.J., McIntosh, R.A. 2001. Mapping of durable adult plant and seedling resistances to stripe rust and stem rust diseases in wheat. Aust. J. Agric. Res. 52:1247-1255.

Dyck, P.L. 1992. Transfer of a gene for stem rust resistance from Tricitum araraticum to hexaploid wheat. Genome 35:788-792. 
Gupta, P., Balyan, H., Edwards, K., Isaac, P., Korzun, V., Röder, M., Gautier, M-F., Joudrier, P., Schlatter, A., Dubcovsky, J., De la Pena, R., Khairallah, M., Penner, G., Hayden, M., Sharp, P., Keller, B., Wang, R., Hardouin, J., Jack, P., Leroy, P. 2002. Genetic mapping of 66 new microsatellite (SSR) loci in bread wheat. Theor. Appl. Genet. 105:413-422.

Jin, Y., Singh, R.P. 2006. Resistance in U.S. wheat to recent eastern African isolates of Puccinia graminis f. sp. tritici with virulence to resistance gene Sr31. Plant Dis. 90:476-480.

Jin, Y., Singh, R.P., Ward, R.W., Wanyera, R., Kinyua, M., Njau, P., Fetch, T., Pretorius, Z.A., Yahyaoui, A. 2007. Characterization of seedling infection types and adult plant infection responses of monogenic $\mathrm{Sr}$ gene lines to race TTKS of Puccinia graminis f. sp. tritici. Plant Dis. 91:1096-1099.

Jin, Y., Szabo, L.J., Pretorius, Z.A., Singh, R.P., Ward, R., Fetch, T., Jr. 2008. Detection of virulence to resistance gene Sr24 within race TTKS of Puccinia graminis f. sp. tritici. Plant Dis. 92:923-926.

Korbie, D.J., Mattick, J.S. 2008. Touchdown PCR for increased specificity and sensitivity in PCR amplification. Nat. Protoc. 3:1452-1456.

Kosambi, D.D. 1944. The estimation of map distances from recombination values. Ann. Eugen. 12:172-175.

Kuchel, H., Fox, R., Reinheimer, J., Mosionek, L., Willey, N., Bariana, H., Jefferies, S. 2007. The successful application of a marker-assisted wheat breeding strategy. Mol. Breed. 20:295-308.

Leonard, K.J. 2001. Stem rust-future enemy? In: Peterson, P.D. (ed.), Stem Rust of Wheat: From Ancient Enemy to Modern Foe. APS Press. St. Paul, MN, USA. pp. 119-146.

Leonard, K.J., Szabo, L.J. 2005. Stem rust of small grains and grasses caused by Puccinia graminis. Mol. Plant Pathol. 6:99-111.

McFadden, E.S. 1930. A successful transfer of emmer characters to vulgare wheat. J. Am. Soc. Agron. 22:1020-1034.

McIntosh, R.A. 1988. The role of specific genes in breeding for durable stem rust resistance in wheat and triticale. In: Simmonds, N.W., Rajaram, S. (eds), Breeding Strategies for Resistance to the Rust of Wheat. CIMMYT. El Batan, Mexico. pp. 1-9.

Michelmore, R.W., Paran, I., Kesseli, R.V. 1991. Identification of markers linked to disease-resistance genes by bulked segregant analysis: a rapid method to detect markers in specific genomic regions by using segregating populations. Proc. Natl Acad. Sci. USA 88:9828-9832.

Nyquist, N.E. 1962. Differential fertilization in the inheritance of stem rust resistance in hybrids involving a common wheat strain derived from Triticum timopheevii. Genetics 47:1109-1124.

Pallotta, M.A., Warner, P., Fox, R.L., Kuchel, H., Jefferies, S.J., Langridge, P. 2003. Marker assisted wheat breeding in the southern region of Australia. Proc. Tenth Int. Wheat Genet. Symp. Paestum, Italy. pp. 789-791.

Pederson, W.L., Leath, S. 1988. Pyramiding major genes for resistance to maintain residual effects. Annu. Rev. Phytopathol. 26:369-378.

Pestsova, E., Ganal, M.W., Röder, M.S. 2000. Isolation and mapping of microsatellite markers specific for the D genome of bread wheat. Genome 43:689-697.

Pretorius, Z.A., Singh, R.P., Wagoire, W.W., Payne, T.S. 2000. Detection of virulence to wheat stem resistance gene Sr31 in Puccinia graminis f. sp. tritici in Uganda. Plant Dis. 84:203.

Rees, R.G. 1972. Uredospore movement and observations on the epidemiology of wheat rusts in north-eastern Australia. Agric. Res. 23:215-223.

Reynolds, M.P., Borlaug, N.E. 2006. Applying innovations and new technologies from international collaborative wheat improvement. J. Agric. Sci. 144:95-110.

Röder, M.S., Korzun, V., Wandehake, K., Planschke, J., Tixier, M.H., Leroy, P., Ganal, M.W. 1998. A microsatellite map of wheat. Genetics 149:2007-2023.

Roelfs, A.P. 1977. Foliar fungal diseases of wheat in the People's Republic of China. Plant Dis. Rep. 61:836841.

Roelfs, A.P., Martens, J.W. 1988. An international system of nomenclature for Puccinia graminis f. sp. tritici. Phytopath. 78:526-533.

Singh, R.P., Hodson, D.P., Huerta-Espino, J., Jin, Y., Bhavani, S., Njau, P., Herrera-Foessel, S.A., Singh, P., Singh, S., Govindan, V. 2011. The emergence of Ug99 races of the stem rust fungus is a threat to world wheat production. Ann. Rev. Phytopath. 49:465-481. 
Somers, D.J., Isaac, P., Edwards, K. 2004. A high-density microsatellite consensus map for bread wheat (Triticum aestivum L.). Theor. Appl. Genet. 109:1105-1114.

Song, Q.J., Shi, J.R., Singh, S., Fickus, E.W., Costa, J.M., Lewis, J., Gill, B.S., Ward, R., Cregan, P.B. 2005. Development and mapping of microsatellite (SSR) markers in wheat. Theor. Appl. Genet. 110:550-560.

Stakman, E.C., Steward, D.M., Loegering, W.Q. 1962. Identification of physiologic races of Puccinia graminis var. tritici. U.S. Dep. Agric. Agric. Res. Serv. E-617.

Tsilo, T.J., Jin, Y., Anderson, J.A. 2008. Diagnostic microsatellite markers for the detection of stem rust resistance gene Sr36 in diverse genetic backgrounds of wheat. Crop Sci. 48:253-261.

Van Ooijen, J.W. 2012. JoinMap ${ }^{\circledR}$ 4.1, Software for the calculation of genetic linkages maps in experimental populations of diploid species. Kyazma B.V. Wageningen, The Netherlands.

Varshney, R.K., Hoisington, D.A., Nayak, S.N., Graner, A. 2009. Molecular plant breeding: methodology and achievements. In: Somers, D.J. et al. (eds), Plant Genomics Methods and Protocols. Humana Press New York, NY. USA. pp. 283-304.

Wanyera, R., Kinyua, M.G., Jin, Y., Singh, R.P. 2006. The spread of stem rust caused by Puccinia graminis f. sp. tritici, with virulence on $\mathrm{Sr} 31$ in wheat in Eastern Africa. Plant Dis. 90:113.

Wu, S. 2008. Molecular mapping of stem rust resistance genes in wheat. M.S. diss. Kansas State Univ., Manhattan, Kansas. Available at http://krex.k-state.edu/ dspace/bitstream/2097/905/1/ShuangyeWu2008. pdf. Verified May 302011.

Wu, S., Pumphrey, M., Bai, G. 2009. Molecular mapping of stem rust-resistance gene $S r 40$ in wheat. Crop Sci. 49:1682-1686.

Zadoks, J.C. 1963. Epidemiology of wheat rust in Europe. FAO Plant Prot. Bull. 13:97-108. 